\title{
コーヒー中の過酸化水素生成要因の検討
}

(平成 3 年 2 月 14 日受理)

$\begin{array}{ll}\text { 辻 澄 子*1 } & \text { 柴 田 } \text { 正 }^{* 1} \text { 小原一雄*2 } \\ \text { 岡田 直子*2 } & \text { 伊藤誉志男*1 }\end{array}$

\section{Studies on the Factors Affecting the Formation of Hydrogen Peroxide in Coffee}

\author{
Sumiko Tsuji ${ }^{* 1}$, Tadashi Shibata ${ }^{* 1}$, Kazuo Ohara*2, \\ Naoko OKADA*2 and Yoshio ITo*1 \\ (*1National Institute of Hygienic Sciences, Osaka Branch: 1-1-43, Hoenzaka, Chuo-ku, \\ Osaka, Japan; *2Japan Food Research Laboratories, Osaka Branch: 3-1, \\ Toyotu-cho, Suita-shi, Osaka, Japan)
}

The factors affecting formation of hydrogen peroxide $\left(\mathrm{H}_{2} \mathrm{O}_{2}\right)$ in coffee have been studied. $\mathrm{H}_{2} \mathrm{O}_{2}$ in coffee was identified by TLC and determined by using an oxygen electrode method and modified 4-aminoantipyrine colorimetry. $\mathrm{H}_{2} \mathrm{O}_{2}$ was not detected in green coffee beans, but was detected in coffee infusion. Coffee infusion or coffee solution prepared using a coffee maker contained less $\mathrm{H}_{2} \mathrm{O}_{2}$ than those prepared using a filfer or a beaker. The greater the degree of roasting, the greater was the formation of $\mathrm{H}_{2} \mathrm{O}_{2}$ in coffee beans. The formation of $\mathrm{H}_{2} \mathrm{O}_{2}$ was also influenced by temperature and light.

Some components of coffee beans, saccharose, chlorogenic acid, glycine, caffeine, caffeic acid and quinic acid, did not contain $\mathrm{H}_{2} \mathrm{O}_{2}$, but when these components were roasted in the same manner as coffee beans and an infusion was prepared, $\mathrm{H}_{2} \mathrm{O}_{2}$ was formed. Formation of $\mathrm{H}_{2} \mathrm{O}_{2}$ from roasted caffeic acid was particularly marked.

(Received February 14, 1991)

Key words：過酸化水素 hydrogen peroxide；コーヒー coffee；薄層クロマトグラフィー thin layer chromatography；酸素電極法 oxygen electrode method; 改良 4-アミノアンチピリン比 色法 modified 4-aminoantipyrine colorimetry；ばい煎 roasting; コーヒー酸 caffeic acid; 熱 分解物 thermal decomposite

緒言

コーヒーに変異原性が認められ1), 2)，その変異原性は 酵素 ${ }^{3) \sim 5)}$ や亜硫酸 (6), 7) により不活化されることから, 過酸 化水素 (以下 $\mathrm{H}_{2} \mathrm{O}_{2}$ ) の存在がクローズアップされるよう になった ${ }^{8)}$.これに関連して種々の分析法で $\mathrm{H}_{2} \mathrm{O}_{2}$ を測定 した報告が見られるようになった ${ }^{92 \sim 12)}$. 著者らは種々の 食品中の $\mathrm{H}_{2} \mathrm{O}_{2}$ 含有量を従来から用いられている酸素電 極法 (従来法) ${ }^{14), 15)}$ で測定したところ, コーヒー（焙り 豆，インスタント）及び茶葉類から $10 \mu \mathrm{g} / \mathrm{g}$ 以上の $\mathrm{H}_{2} \mathrm{O}_{2}$ を検出したが，それらのばらつきは大きかった ${ }^{13)}$. 特に, コーヒーについては, $\mathrm{H}_{2} \mathrm{O}_{2}$ の含有量が大きく, そ

*1 国立衛生試験所大阪支所：大阪市中央区法円坂 1-1-43

*2（財）日本食品分析センター大阪支所; 大阪府吹田市豊津町 $3-1$
のばらつきも非常に大きかった，そこで，コーヒ一中の $\mathrm{H}_{2} \mathrm{O}_{2}$ として定量されているあのが真の $\mathrm{H}_{2} \mathrm{O}_{2}$ であるか よ゙うかを薄層クロマトグラフィー（以下 TLC) で確認し

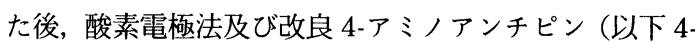
AA） 法 ${ }^{16)}$ により定量し, $\mathrm{H}_{2} \mathrm{O}_{2}$ 生成要因について検討し, 若干の知見が得られたので報告する.さらに、コーヒー 成分についてモデル実験を試み, $\mathrm{H}_{2} \mathrm{O}_{2}$ 生成要因につい て若干の考察を加えたので合わせて報告する.

\section{実験方法}

1. 試料

インド，タンザニア，コロンビア，ペルー，アイボリ 一, ポンジュラル, ウガンダ, エチオピア，ブラジル及 びインドネシアの 10 か国の生コーヒー豆，それらの焙 り豆及びインスタントコーヒーは全日本コーヒー協会よ 


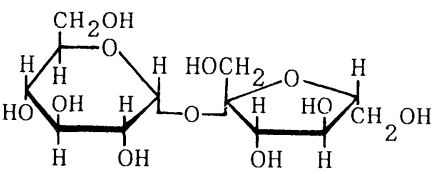

saccharose

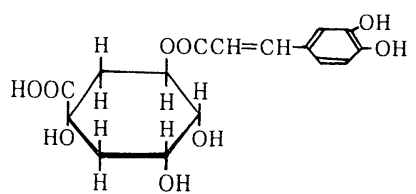

chlorogenic acid
$\mathrm{NH}_{2} \mathrm{CH}_{2} \mathrm{COOH}$

glycine<smiles>Cn1c(=O)c2c(ncn2C)n(C)c1=O</smiles>

caffeine

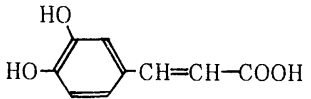

caffeic acid

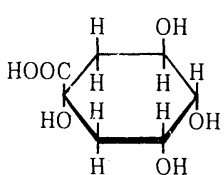

quinic acid

Fig. 1. Chemical structures of various components of green coffee beans

り供与されたものを使用した.

缶入りコーヒーは大阪市内の市場で購入した. Fig. 1 に示したコーヒーの成分であるショ糖, クロロゲン酸, グリシン，コーヒ一酸及びキナ酸はそれぞれ，片山化学 工業(株), 東京化成工業(株), 片山化学工業(株), ナ力 ライテスク(株)から購入した.

\section{2. 試薬}

1) $\mathrm{H}_{2} \mathrm{O}_{2}$ の標準溶液, リン酸緩衝液(1) (以下 PB(1) (pH 7.0) 及びカタラーゼ溶液の調製：従来法 ${ }^{14), 15)}$ に従っ た.

2) 4-AA 溶液, フェノール溶液，リン酸緩衝液(2)（以 下 PB(2)）(pH 7.3) 及びペルオキシダーゼ溶液の調製：伊 藤らの方法 ${ }^{16)}$ に従った.

3） 4-AA 反応試薬の調製：4-AA 溶液，フェノール溶

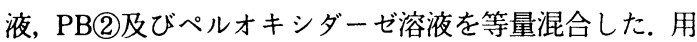
時調製した。

4） TLC 板：東京化成(株)製スポットフィルム®シリ カゲルを用いた。

5) 展開液 (a) 及び (b) の調製：クロロホルムーメタノ 一ル混液 $(5: 4)$ を展開液 (a) として用い，クロロホルムメ夕ノール混液 $(49: 1)$ を展開液 (b) として用いた。

\section{3. 装置}

過酸化水素測定装置：オリエンタル電気(株)社製 Oritector Model III 型

自記分光光度計：日立製作所(株)製 556 型

ドリップ式ろ過器：カリ夕(株)社製

自動型コーヒーメーカー：ナショナル電器(株)社製 NC-A2 型

恒温槽：(株)島津製作所製 GC8A 型

\section{4. 操作方法}

1) コーヒー浸出液及びコーヒ一溶解液の調製方法： 粉砕した焙り豆 $10 \mathrm{~g}$ を熱湯 $\left(90^{\circ}\right) 150 \mathrm{ml}$ を用いてドリ
ップ式によりろ過器またはコーヒーメーカーで浸出し, コーヒー浸出液とした。 また，無菌ボックスに窒素ガス (以下 $\mathrm{N}_{2}$ ) を流してコーヒーメーカーによる浸出液の調 製屯行った。インスタントコーヒー粉末 $2 \mathrm{~g}$ を $200 \mathrm{ml}$ ビーカーまたはコーヒーメーカーに入れ，熱湯 $\left(90^{\circ}\right)$ $150 \mathrm{ml}$ を加えて溶解し，コーヒ一溶解液とした。

2) コーヒ一濃縮液の調製方法：ドリップ式ろ過器を 用いて調製したコーヒー浸出液 $200 \mathrm{ml} 2 \mathrm{ml}$ に減圧 濃縮し，コーヒー濃縮液とした。

3) 脂質の除去法：粉砕した焙り豆 $5 \mathrm{~g}$ はエーテル $100 \mathrm{ml}$ で 2 回洗浄した.

4) TLC (1) 方法 (a): コーヒー濃縮液 $20 \mu \mathrm{l}$ を TLC 板 に塗布し，展開液 (a) で展開後褐色のスポットの有無を 確認した。 さらに 4-AA 反応試薬を噴霧して, 桃色を带 びるか否かを確認した。 $\mathrm{H}_{2} \mathrm{O}_{2}$ 標準液 $(50 \mu \mathrm{g} / \mathrm{ml}) 20 \mu \mathrm{l}$ を塗布して同様に展開して対照とした。

(2) 方法 (b): 調製直後のコーヒー浸出液 $200 \mathrm{ml}$ に 4-AA 反応試薬 $4 \mathrm{ml}$ を加えて反応させ, 伊藤らの 4-AA 法 $^{16)}$ 準じてフロリジルカラム処理した後, $1 \mathrm{ml}$ に減圧 濃縮した。 その $20 \mu \mathrm{l}$ を TLC 板に塗布し, 展開液 (b) で 展開し，桃色のスポットを確認した， $\mathrm{H}_{2} \mathrm{O}_{2}$ 標準液 (100 $\mu \mathrm{g} / \mathrm{ml}) \quad 10 \mathrm{ml}$ に-AA 反応試薬 $4 \mathrm{ml}$ を加えて反応さ せ，以下同様に操作し対照とした。

5) コーヒー成分を用いた際の実験方法

(1) 試料溶液の調製法：中林らの方法 ${ }^{17), 18)}$ に従って, 各コーヒー成分について Table 4 の右欄に記した量をと り, McIlvaine 緩衝液 ${ }^{19)}$ (pH 5.5) $2 \mathrm{ml}$ に溶解させ, 試料 溶液とした。 ただし，クロロゲン酸，コーヒ一酸及び各 成分混合物は完全には溶解しなかったので懸濁液とし た.

(2) ばい煎方法：中林らの方法 ${ }^{17), 18)}$ に従った. 各試料 溶液 $2 \mathrm{ml}$ （コーヒ一生豆 $2 \mathrm{~g}$ に相当する量）を精製セラ 
イト $1.5 \mathrm{~g}$ と混和してコーヒ一成分を吸着させ, 試験管 （丸底 $\phi 1.6 \times 2.5 \mathrm{~cm}$ ）の壁に約 $5 \mathrm{~mm}$ の層状に付着さ せ，同一試料を二つずつ作り，一方は室温下に置き，ば い煎前試料とした。他方は, 恒温槽で $200^{\circ}$ で 15 分間加 熱後, 室温下で 15 分間放冷し, ばい煎後試料とした. ば い煎後試料は，焙り豆 $1.6 \mathrm{~g}$ に対応するものとして以後 の実験を行った.

(3) 浸出方法：ばい煎前及びばい煎後の試料に直ちに $90^{\circ}$ の熱湯を $24 \mathrm{ml}$ 加え, ガラス棒で試験管の壁に付着 させたセライト部分を迅速に 20 回こすりながら浸出し た液を， $0.45 \mu \mathrm{m}$ のメンブランフィルターでろ過し試験 溶液とした。これらはコーヒー焙り豆 $10 \mathrm{~g}$ を熱湯 150 $\mathrm{ml}$ で浸出した液に対応するものとして実験を行った。

(4) $\mathrm{H}_{2} \mathrm{O}_{2}$ 生成率の計算方法: 各コーヒ一成分浸出液 中の $\mathrm{H}_{2} \mathrm{O}_{2}$ 濃度 $(\mu \mathrm{g} / \mathrm{ml})$ に熱湯の量 $24 \mathrm{ml}$ を乗じた值を 各 $\mathrm{H}_{2} \mathrm{O}_{2}$ 生成量とし, その生成量を各成分量で割り, 分 率で示した值を $\mathrm{H}_{2} \mathrm{O}_{2}$ 生成率とした。同一重量の成分か ら生成してくる $\mathrm{H}_{2} \mathrm{O}_{2}$ 量の分率である.

6) $\mathrm{H}_{2} \mathrm{O}_{2}$ の测定方法

(1) 酸素電極法 (i) 固体試料:

[酸素電極法(1)] 従来法 ${ }^{14), 15)}$ に従って行った. すなわ ち, 粉砕した固体試料 $5.0 \mathrm{~g}$ をとり, 消泡剂 (シリコーン 樹脂） 1 滴及び PB(1) $40 \mathrm{ml}$ を加え，ホモジナイズした 後, ろ紙ろ過し，乃液を試料液とした，ただし，PB(1)を 加えてからろ液を得るまでの間を 10 分以内とした。試 料液 $2 \mathrm{ml}$ を直ちに酸素電極装置の試料セル内に入れ $\mathrm{N}_{2}$ で酸素を追い出した後, カタラーゼを加えて $\mathrm{H}_{2} \mathrm{O}_{2}$ を 分解して生じた酸素を測定し, 同様に操作した $\mathrm{H}_{2} \mathrm{O}_{2}$ の 標準溶液の検量線より試料中の $\mathrm{H}_{2} \mathrm{O}_{2}$ を算出した。

[酸素電極法(2)] 酸素電極装置のセル内に PB(1) $2.0 \mathrm{ml}$ を入れ, あらかじめ $\mathrm{N}_{2}$ を通気して酸素を追い出した後, 粉砕した固体試料 $20 \mathrm{mg}$ をセル内に入れ，1 分以内に カタラーゼを加え, 以下酸素電極法(1)と同様に操作し た。

(ii) 液体試料: [酸素電極法(3) ] 酸素電極法(2)に相当 する辻らの方法 ${ }^{20)} に$ 従った. すなわち, 酸素電極装置の セル内に, PB(1) $1.0 \mathrm{ml}$ を入れ, あらかじめ $\mathrm{N}_{2}$ を通気し て酸素を追い出した後, 液体試料 $1 \mathrm{ml}$ をセル内に入れ,
$\mathrm{N}_{2}$ を通気して，液体試料を加えてから 1 分以内に力夕 ラーゼを加え，以下酸素電極法(1)と同様に操作した.

(2) 4-AA 法：伊藤らの方法 ${ }^{16)}$ に従った.

7) 過酸化物価（以下 POV）の測定：衛生試験法・注 解 $^{21)}$ に従って, ヨウ化カリウムの酸化物として測定し た. だたし, 試料の量はコーヒ一焙り豆に含有されてい る油脂の量ではなく，焙り豆の量とした。

(8) 焙り豆の保存方法: 種々の温度の恒温槽内で焙り 豆を 600 ルックスの白色けい光灯下または遮光して保 存した.

\section{実験結果及び考察}

\section{1. コーヒー液の $\mathbf{p H}$}

コーヒー浸出液, インスタントコーヒ一液及び缶コー ヒーの液性を調べた。

Table 1 に示したように, ミルクの入った缶コーヒー 以外はいずれあ酸性であった。 コーヒ一中の $\mathrm{H}_{2} \mathrm{O}_{2}$ を酸 素電極法で測定する場合にはカタラーゼの至適 $\mathrm{pH}$ でな ければならない。そこで，アスコルビン酸含有清涼飲料 水 ${ }^{201}$ の場合と同様に PB(1)による 2 倍以上の希釈が必要 となり, 希釈時には, アスコルビン酸含有清涼飲料水 ${ }^{20)}$ のように, コーヒ一成分から $\mathrm{H}_{2} \mathrm{O}_{2}$ が生成する可能性が ある.したがって，液体試料はアスコルビン酸含有清涼 飲料水と同樣に酸素電極装置の試料セル内で希釈して 1 分以内に $\mathrm{H}_{2} \mathrm{O}_{2}$ を測定する酸素電極法(3)を用いることに より空気酸化の影響を除いた.

\section{2. コーヒー液中の $\mathrm{H}_{2} \mathrm{O}_{2}$ の確認}

インド産コーヒー焙り豆（ばい煎度：H-i, Table 2 参

Table 1. pH Ranges of Commercial Coffees and Coffee Beverages at Drinking Concentration

\begin{tabular}{cc}
\hline \hline Sample & Range of $\mathrm{pH}\left(n^{*}\right)$ \\
\hline Soluble coffee solution & $4.8 \sim 5.2(10)$ \\
Regular coffee infusion & $4.9 \sim 5.5(10)$ \\
Liquid coffee beverage & $6.3 \sim 6.9(5)$ \\
with milk type & \\
without milk type & $4.8 \sim 5.6(5)$ \\
\hline
\end{tabular}

$*_{n}$ : Number of samples

Table 2. Effects of Roasting Degree on $\mathrm{H}_{2} \mathrm{O}_{2}$ Contents in Roasted Coffee Beans $\rightarrow$ deeper

\begin{tabular}{|c|c|c|c|c|c|c|c|c|c|c|}
\hline \multirow{3}{*}{$\begin{array}{c}\text { Roasting } \\
\text { degree }\end{array}$} & \multicolumn{3}{|c|}{$\mathrm{L}^{*}$} & \multicolumn{3}{|c|}{$\mathrm{M}^{*}$} & \multicolumn{4}{|c|}{$\mathrm{H}^{*}$} \\
\hline & $\mathrm{i}$ & ii & iii & $\mathrm{i}$ & ii & iii & $\mathrm{i}$ & ii & iii & iv \\
\hline & \multicolumn{10}{|c|}{ Concn, of $\mathrm{H}_{2} \mathrm{O}_{2}(\mu \mathrm{g} / \mathrm{g})$} \\
\hline Indian beans & 54 & 62 & 72 & 71 & 89 & 89 & 110 & 110 & 140 & 150 \\
\hline Brazilian beans & 68 & 59 & 77 & 120 & 110 & 120 & 120 & 140 & 140 & 150 \\
\hline
\end{tabular}

These values are averages of three determinations.

* Coffee beans were roasted in different roasting degrees. 


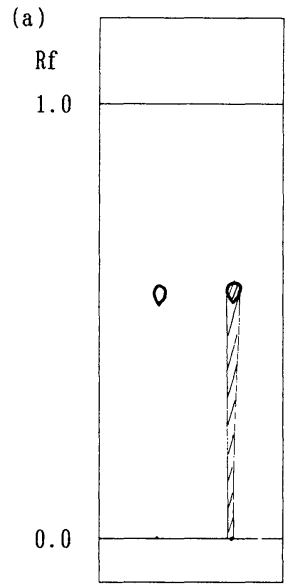

(1) (2) (b)

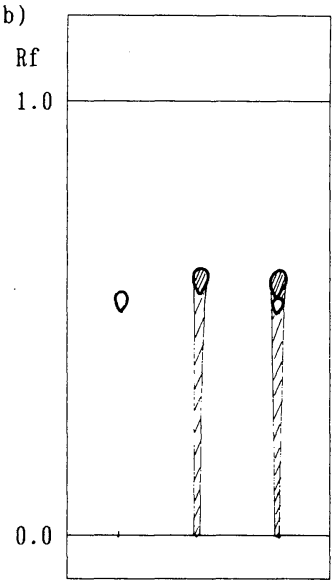

(3) (4) (5)
Fig. 2. Thin layer chromatograms of coffee concentrates

Samlpe: (1) $\mathrm{H}_{2} \mathrm{O}_{2}$ standard solution; (2) coffee concentrate; (3) $\mathrm{H}_{2} \mathrm{O}_{2}$ standard solution reacted with coloring reagent; (4)coffee concentrate; (5)coffee concentrate reacted with coloring reagent

Developing solvent $\left(\mathrm{CHCl}_{3}: \mathrm{MeOH}\right)$ (a) $5: 4$; (b) $49: 1$

Coloring reagent: mixture solution of 4-AA, phenol, peroxidase and phosphate buffer (pH 7.3)

照）をドリップ式ろ過器を用いて浸出した。 そのコーヒ 一浸出液を酸素電極法(3) (カタラーゼ処理) ${ }^{20)}$ 並びに4AA 法 (ペルオキシダーゼ処理) ${ }^{16)}$ により測定したとこ ろ, 浸出液中の $\mathrm{H}_{2} \mathrm{O}_{2}$ 含量は平均值 (3 試行) として 2.63 $\mu \mathrm{g} / \mathrm{ml}$ 及び $2.60 \mu \mathrm{g} / \mathrm{ml}$ であった． 測定原理が異なるに むかかわらず定量值が極めて近いことから，両法により 定量された值は $\mathrm{H}_{2} \mathrm{O}_{2}$ によるものであると考えられる. 山東ら ${ }^{22)}$ はエーテル洗浄により過酸化脂質由来の $\mathrm{H}_{2} \mathrm{O}_{2}$ を除去している. コーヒー焙り豆をエーテルにより脱脂 した後, 浸出した液中の $\mathrm{H}_{2} \mathrm{O}_{2}$ 值には変化がなかった. したがって，コーヒー中の $\mathrm{H}_{2} \mathrm{O}_{2}$ 值は過酸化脂質が要因 ではないと考えられる.

このコーヒー浸出液を濃縮したものを試験液とし, 直 ちに展開溶媒 (a) を用いて TLC を行った. 展開後の TLC プレートは $\mathrm{H}_{2} \mathrm{O}_{2}$ 標準液と同様の $\mathrm{R} f$ 值に褐色のス ポットが観察され，4-AA 試薬を噴霧すると桃色を帯び たスポットに変化した．TLCの塗布あるいは 4-AA 試 薬の噴霧が遅れると桃色を帯びた褐色のスポットが得ら れず，褐色のスポットのみであった，そこで，さらにコ 一七一浸出液に 4-AA 試薬を反応させた後濃縮したもの について，直ちに展開溶媒 (b) を用いて TLC を行った。 4-AA 試薬を反応させなかったコーヒー成分のスポット

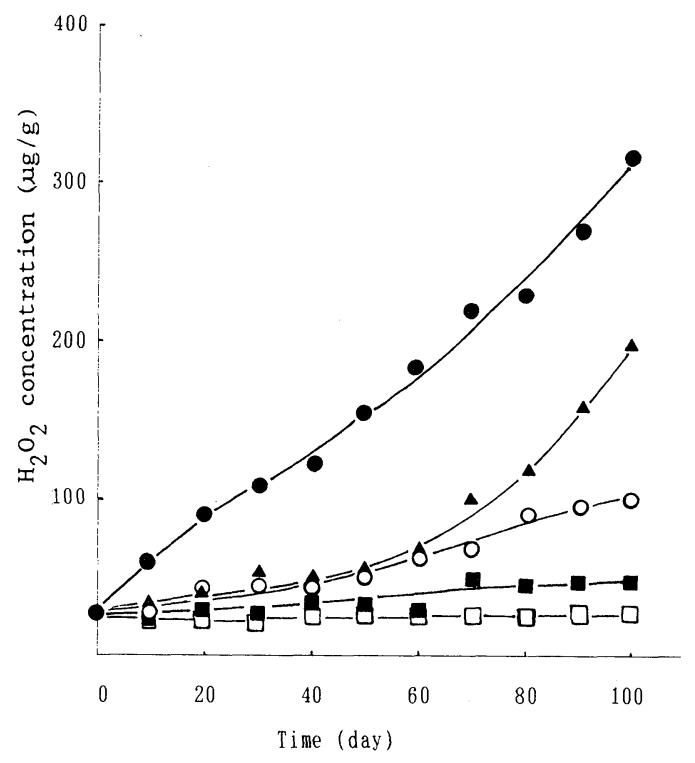

Fig. 3. Effects of temperature and light on $\mathrm{H}_{2} \mathrm{O}_{2}$ content in roasted coffee beans

: at $35^{\circ} \mathrm{C}$ with light; $\boldsymbol{\Delta}$ : at $25^{\circ} \mathrm{C}$ with light

口: at $5^{\circ} \mathrm{C}$ with light; $\bigcirc$ : at $35^{\circ} \mathrm{C}$ in the dark $\square$ : at $5^{\circ} \mathrm{C}$ in the dark

は褐色であり, $\mathrm{H}_{2} \mathrm{O}_{2}$ の呈色物 (Fig. 2(b) (3) の桃色のス ポットとは異なった $\mathrm{R} f$ 值を示した. したがって，コー ヒ一濃縮液 (Fig. 2(b) (5)) 中のコーヒ一成分と $\mathrm{H}_{2} \mathrm{O}_{2}$ 呈色 物の桃色のスポットが区別できた。 また，コーヒーを浸 出してから濃縮して 4-AA 試薬を反応させるまでの時間 が長かった場合は, $\mathrm{H}_{2} \mathrm{O}_{2}$ 呈色物の桃色のスポットが得 られなかった. すなわち, コ一ヒ一中の $\mathrm{H}_{2} \mathrm{O}_{2}$ をTLCで 確認でき，その $\mathrm{H}_{2} \mathrm{O}_{2}$ は時間の経過により消失すること が明らかになった。

3. コーヒー豆について

10 か国の生コーヒー豆を酸素電極法(1)により測定し たが, $\mathrm{H}_{2} \mathrm{O}_{2}$ は検出されなかった.

インド及びブラジル産の生コーヒ一豆を種々のばい煎 法でばい煎した焙り豆について酸素電極法(1)により $\mathrm{H}_{2} \mathrm{O}_{2}$ を測定した。

$\mathrm{H}_{2} \mathrm{O}_{2}$ 含有量は Table 2 に示した. ばい煎度は L, M, H になるほよ゙深く，その中でも i, ii, iii と番号が大きい方 が深くなる，したがって，ばい煎度が深くなるほど， $\mathrm{H}_{2} \mathrm{O}_{2}$ 含量が高くなった。

また, インド産焙り豆 (L-i) を豆のまま光照射あるい は暗所にて各種温度で保存したときの $\mathrm{H}_{2} \mathrm{O}_{2}$ 含量の変化 を酸素電極法(1)により検討した。

Fig. 3 に示したように，暗所に保存しても， $35^{\circ}$ の保 存温度では, $\mathrm{H}_{2} \mathrm{O}_{2}$ 含有量の上昇が見られ，光照射によ り,さらに上昇した。 


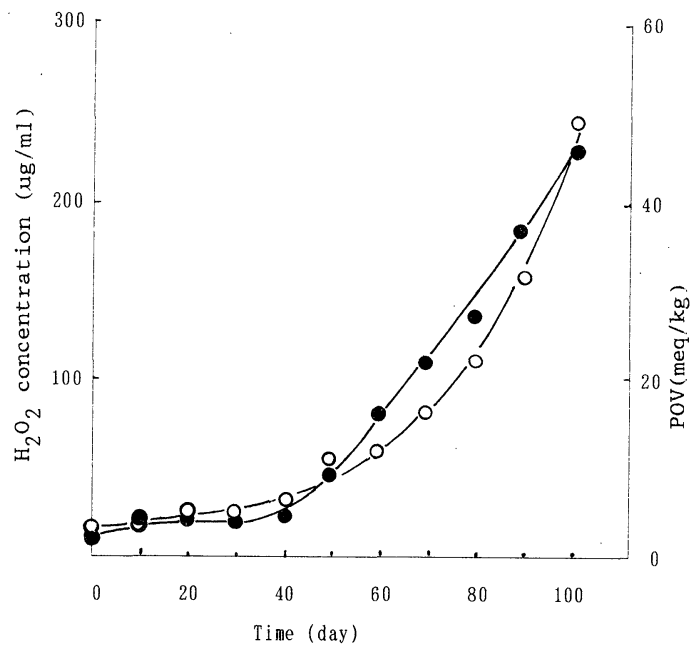

Fig. 4. Time course of $\mathrm{H}_{2} \mathrm{O}_{2}$ content and $\mathrm{POV}$ of roasted coffee beans

Roasted coffee beans stored with light at $30^{\circ} \mathrm{C}$.

$\mathrm{O}: \mathrm{H}_{2} \mathrm{O}_{2}$ content; $\mathrm{POV}$

インド産焙り豆 (L-i) の異なるロットの豆を保存温度 $30^{\circ}$, 光照射の条件で, 保存したときの $\mathrm{H}_{2} \mathrm{O}_{2}$ 含有量と POV 值との関係を Fig. 4 に示した.

Fig. 3 と同じインド産焙り豆を用いたが，ロットが異 なるためか, $\mathrm{H}_{2} \mathrm{O}_{2}$ 值が少し低い值を示した. $\mathrm{H}_{2} \mathrm{O}_{2}$ 含有 量と POV 值は比例関係を示すことから，POV 值はほと んど $\mathrm{H}_{2} \mathrm{O}_{2}$ に起因する值と考えられる.

コーヒ一焙り豆を粉砕して, 室温, 冷暗所で約 1 か月 間保存しても, $\mathrm{H}_{2} \mathrm{O}_{2}$ 含有量値に変化は見られなかった.

コーヒー中の $\mathrm{H}_{2} \mathrm{O}_{2}$ はアスコルビン酸を含有する清凉 飲料水 ${ }^{19)}$ と同様に，溶存酸素によるコーヒー成分の自動 酸化により生成すると考えられている ${ }^{81,12)}$. したがって, コーヒーの試料溶液を調製する際にも $\mathrm{H}_{2} \mathrm{O}_{2}$ が生成して いる可能性がある.そこで，溶存酸素の影響が少なくな るようにした酸素電極法(2) と従来法 ${ }^{14), 15)}$ である酸素電 極法(1)の両法を用いて, インド産焙り豆 (M-ii) 中の $\mathrm{H}_{2} \mathrm{O}_{2}$ の測定值を比較してみたところ，(2)では $12 \pm$ $2 \mu \mathrm{g} / \mathrm{g}$ となり, (1)では $89 \pm 7 \mu \mathrm{g} / \mathrm{g}$ であった. $\mathrm{H}_{2} \mathrm{O}_{2} 100$ $\mu \mathrm{g} / \mathrm{g}$ 添加時の(2)による回収率は $92 \%$ であったことを 考え合わせると酸素電極法(1)では操作中に約 $80 \mu \mathrm{g} / \mathrm{g}$ の $\mathrm{H}_{2} \mathrm{O}_{2}$ が生成されたことになる。

\section{4. インスタントコーヒーについて}

インスタントコーヒーはコーヒー焙り豆を各メーカー 独自の方法で浸出して乾燥した粉末である. 酸素電極法 (1)を用いて測定した $\mathrm{H}_{2} \mathrm{O}_{2}$ 值は $194 \pm 11 \mu \mathrm{g} / \mathrm{g}$ であり, 酸素電極法(2)では $22 \pm 4 \mu \mathrm{g} / \mathrm{g}$ であった. インスタント コーヒーにおいても, 酸素電極法(1)による测定では操作 中に $\mathrm{H}_{2} \mathrm{O}_{2}$ が生成され，その生成量は約 $170 \mu \mathrm{g} / \mathrm{g}$ であ り, 焙り豆より多かった. インスタントコーヒーは一度
Table 3. Effects of Coffee Preparation of $\mathrm{H}_{2} \mathrm{O}_{2}$ in Coffee Infusion and Solution

\begin{tabular}{|c|c|c|}
\hline \multirow{3}{*}{ Sample } & \multicolumn{2}{|c|}{ Preparation method } \\
\hline & \multicolumn{2}{|r|}{$\mathrm{H}_{2} \mathrm{O}_{2}(\mu \mathrm{g} / \mathrm{ml})$} \\
\hline & $\begin{array}{l}\text { Filter or } \\
\text { Beaker*1 }\end{array}$ & $\begin{array}{l}\text { Coffee maker*2 } \\
\text { in the air } \\
\text { (in the } \mathrm{N}_{2} \text { flow) }\end{array}$ \\
\hline \multirow[t]{4}{*}{ Coffee infusion $* 3$} & (1) $4.8 \pm 0.6$ & $0.4 \pm 0.2(0.1 \pm 0.1)$ \\
\hline & (2) $5.5 \pm 1.6$ & $0.2 \pm 0.2(\mathrm{ND})$ \\
\hline & (3) $4.4 \pm 0.4$ & $0.1 \pm 0.1(\mathrm{ND})$ \\
\hline & (4) $5.0 \pm 1.0$ & $0.2 \pm 0.1(\mathrm{ND})$ \\
\hline \multirow{3}{*}{$\begin{array}{l}\text { Soluble coffee } \\
\text { solution*4 }\end{array}$} & (A) $6.7 \pm 1.6$ & $0.6 \pm 0.3$ \\
\hline & (B) $4.8 \pm 0.8$ & $0.3 \pm 0.2$ \\
\hline & (C) $5.6 \pm 0.8$ & $0.5 \pm 0.2$ \\
\hline
\end{tabular}

$\mathrm{ND}<0.1 \mu \mathrm{g} / \mathrm{ml}$

Data show mean values $\pm \mathrm{SD}$ of 3 determinations

*1 Infusion and solution were prepared using filter and beaker, respectively.

*2 Infusion and solution were prepared using automatic coffee maker.

*3 The roasted coffee beans of different countries were ground and infused.

*4 The soluble coffee powders produced by various manufactories were dissolved.

浸出したものを乾燥しているため, インスタントコーヒ 一粉末中のコーヒ一成分の含量がコーヒ一焙り豆中より 多く存在している ${ }^{23)}$. したがって, $\mathrm{H}_{2} \mathrm{O}_{2}$ 生成量が多くな った原因としては $\mathrm{H}_{2} \mathrm{O}_{2}$ 量が焙り豆の $12 \mu \mathrm{g} / \mathrm{g}$ からイン スタントコーヒーの $22 \mu \mathrm{g} / \mathrm{g}$ と増加しているだけでな $<, \mathrm{H}_{2} \mathrm{O}_{2}$ 前駆物質が多量存在していると考えられ, 酸素 電極法(1)の操作中に溶存酸素の影響で $\mathrm{H}_{2} \mathrm{O}_{2}$ 生成量が増 加したと考えられる.

5. コーヒー液について

焙り豆及びインスタントコーヒーのいずれにおいても 試料溶液調製時に $\mathrm{H}_{2} \mathrm{O}_{2}$ が生成することが考えられたの で,コーヒー液について検討した。

コーヒ一焙り豆を粉砕し, ドリップ式でろ過器を用い た方法及びコーヒーメーカーを用いた方法により浸出液 を調製した. コーヒーメーカーの場合は $\mathrm{N}_{2}$ 気流中でも 調製した。 また，インスタントコーヒーの溶解はビーカ 一に入れて通常溶解する方法及びコーヒーメ一カーに入 れて溶解する方法によりコーヒ一液を調製した。 その結 果を Table 3 に示した.

著者らがろ過器で調製したコーヒー液中の $\mathrm{H}_{2} \mathrm{O}_{2}$ 值, $5 \mu \mathrm{g} / \mathrm{ml}$ はけい光反応速度法によるコーヒ一液中の $\mathrm{H}_{2} \mathrm{O}_{2}$ 值, $250 \sim 300 \mu M(8.5 \sim 10.2 \mu \mathrm{g} / \mathrm{ml})^{11)}$ に類似して おり,コーヒー液の調製時においても, 試料液の調製時 


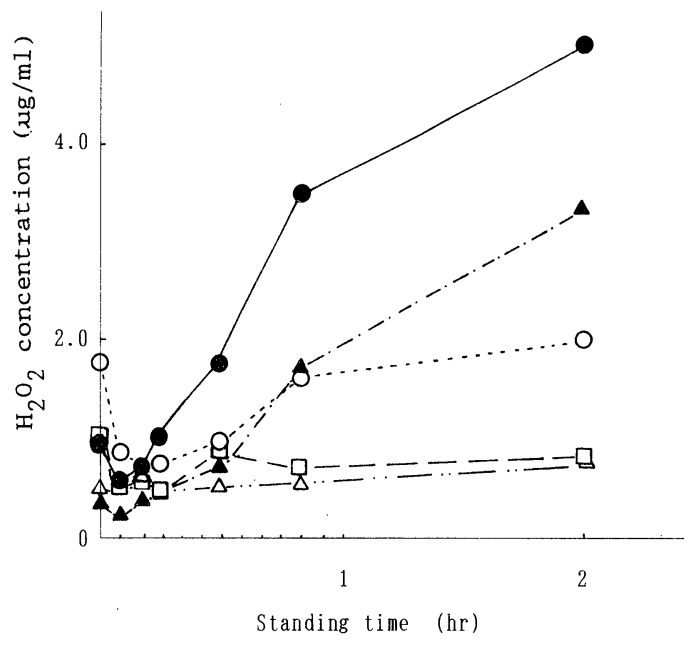

Fig. 5. Time course of $\mathrm{H}_{2} \mathrm{O}_{2}$ content in coffee solution

-: regular coffee infusion, standing in glass server without cap

$\bigcirc$ : regular coffee infusion, placed on a hot plate

$\square$ : regular coffee infusion in glass server with special cap on surface of the solution, placed on a hot plate

$\Delta$ : soluble coffee solution, standing in glass server without cap

$\triangle$ : soluble coffee solution, placed on a hot plate

之同様にコーヒ一成分からの $\mathrm{H}_{2} \mathrm{O}_{2}$ の生成が考えられ る. 一方, 著者らがコーヒーメーカーで調製したコーヒ 一液中の $\mathrm{H}_{2} \mathrm{O}_{2}$ 值に近く, $\mathrm{N}_{2}$ 気流中においてコーヒーメ 一カーで調製したコーヒ一浸出液からは $\mathrm{H}_{2} \mathrm{O}_{2}$ をほとん ど検出しなかった。これは，Rinkus et al. のドリップ式 の自動式コーヒーメーカーを用いて調製した浸出液中に は $\mathrm{H}_{2} \mathrm{O}_{2}$ をほとんど検出していない(12) という結果と類似 しており，コーヒ一液中の溶存酸素量が異なることによ り, $\mathrm{H}_{2} \mathrm{O}_{2}$ の生成量が異なったという彼らの考えを支持 する結果であった。したがって，コーヒーメーカーは溶 存酸素が少ない状態でコーヒーを調製していると考えら れる.

また，コーヒー液の保存時間による $\mathrm{H}_{2} \mathrm{O}_{2}$ 量の変化を 酸素電極法(2)により測定した結果, Fig. 5 に示したよう に, $\mathrm{H}_{2} \mathrm{O}_{2}$ 生成はホットプレート上のコーヒーが最も少 なかった.これらの結果も, Rinkus et al. ${ }^{12)}$ のコーヒー を口まで満たして蓋をした場合や $90^{\circ}$ で保存した場合の コーヒーからは $\mathrm{H}_{2} \mathrm{O}_{2}$ を検出しなかった結果と非常に類 似しており，前述したようにコーヒ一液中の溶存酸素量 の差により $\mathrm{H}_{2} \mathrm{O}_{2}$ の生成量が異なるという彼らの考えを 同様に支持するものである.
Table 4. Contents of Various Components in Green Coffee Beans Used for Roasting

\begin{tabular}{lcc}
\hline \hline Component & $\begin{array}{c}\text { Content (\%) } \\
\text { used for } \\
\text { roasting*1 }\end{array}$ & $\begin{array}{c}\text { Amount }(\mathrm{mg}) \\
\text { used for } \\
\text { roasting*2 }\end{array}$ \\
\hline Saccharose & 8.0 & 160 \\
Chlorogenic & 7.0 & 140 \\
$\quad$ acid & 2.1 & 42 \\
Glycine & 1.5 & 30 \\
Caffeine & 0.3 & 6 \\
Caffeic acid & 2.2 & 44 \\
$\begin{array}{l}\text { Quinic acid } \\
\text { (Others*3 }\end{array}$ & 78.9 & - ) \\
Total & 100.0 & - \\
\hline Mixture of 6 & 21.1 & 422 \\
$\quad$ components & & \\
\hline
\end{tabular}

Each component or mixture of 6 components in Mcllvaine's buffer solution $(2 \mathrm{ml})$ was absorbed on the celite $(1.5 \mathrm{~g})$, and then roasted.

*1 These contents were decided by reference to refs. ${ }^{17,}, 23 \sim 25$ )

*2 Amount of each component corresponds to one contained in $2 \mathrm{~g}$ of green coffee beans.

*3 These components mean protein, fiber, water, etc., and were not used for roasting except for water.

したがって，コーヒー中の成分が溶存酸素の影響によ り $\mathrm{H}_{2} \mathrm{O}_{2}$ を生成し，また，それらの成分が分解していく 一方 $\mathrm{H}_{2} \mathrm{O}_{2}$ あ分解していくことが考えられ, $\mathrm{H}_{2} \mathrm{O}_{2}$ 量は測 定した時点での量として捉えているすのと考えられる。

\section{6. コーヒー成分について}

\section{1 生豆中の成分からの $\mathrm{H}_{2} \mathrm{O}_{2}$ 生成について}

生豆中のコーヒー成分組成 ${ }^{23 \sim 25}$ 並びに褐色色素形成 のモデルばい煎のときの成分組成 ${ }^{17}$ を参考にして，コー ヒ一中の $\mathrm{H}_{2} \mathrm{O}_{2}$ 生成のモデルばい煎の成分組成を Table 4 のように仮定した. Table 4 の 6 成分の自動酸化の有 無を調べるために，各水溶液 $(100 \mu \mathrm{g} / \mathrm{ml})$ に空気を通気 した. 空気通気前後の水溶液中の $\mathrm{H}_{2} \mathrm{O}_{2}$ を酸素電極法(3) を用いて測定したところ, Table 5 に示したように，通 気前では $\mathrm{H}_{2} \mathrm{O}_{2}$ を検出しなかったが, 通気後ではショ糖, クロロゲン酸及びコーヒー酸からは $\mathrm{H}_{2} \mathrm{O}_{2}$ を検出し, こ れらは自動酸化しやすい物質であることが分かった。こ れらはコーヒー中の香りの研究 ${ }^{26 a)}$ 及び食品の褐変現象 の研究 ${ }^{277}$, 28) から, ショ糖のメイラード反応及びポリフェ ノールの自動酸化 ${ }^{29)}$ として種々研究されているが，コー ヒ一中の $\mathrm{H}_{2} \mathrm{O}_{2}$ 含有量に対し自動酸化により生成される 量は少なすぎる，そこで，各成分をばい煎したものから の $\mathrm{H}_{2} \mathrm{O}_{2}$ 量を測定することにした。 


\section{2 ばい煎したコーヒー成分からの $\mathrm{H}_{2} \mathrm{O}_{2}$ 生成につ} いて

Table 4 に示した重量\%に相当する量，すなわちコー ヒ一生豆 $2 \mathrm{~g}$ に含有されると考えられる各成分の重量を セライトに吸着させて，ばい煎し浸出した液中の $\mathrm{H}_{2} \mathrm{O}_{2}$ を酸素電極法(3)を用いて測定した，浸出するときの熱湯 量はコーヒー焙り豆 $10 \mathrm{~g}$ を熱湯 $150 \mathrm{ml}$ で浸出すると きの量比と同じになるようにした.すなおち, コーヒー 生豆はばい煎することにより，その重量が $80 \%$ に減少 する ${ }^{30)}$ こから, 生豆 $2.0 \mathrm{~g}$ は焙り豆 $1.6 \mathrm{~g}$ に相当し，そ れを熱湯 $24 \mathrm{ml}$ で浸出した液がコーヒー浸出液に相当 する.

Table 5. Concentration of $\mathrm{H}_{2} \mathrm{O}_{2}$ in Aquious Solutions or Suspension Solutions of Coffee Components

\begin{tabular}{lccl}
\hline \hline \multirow{2}{*}{ Component } & \multicolumn{3}{c}{ Content of $\mathrm{H}_{2} \mathrm{O}_{2}(\mu \mathrm{g} / \mathrm{ml})$} \\
\cline { 2 - 3 } & \multicolumn{2}{c}{ Bubbling } & \\
\cline { 2 - 3 } & Before & After* & Appearance \\
\hline Saccharose & ND & 0.09 & Clear solution \\
Chlorogenic acid & ND & 0.06 & Suspension \\
Glycine & ND & ND & Clear solution \\
Caffeine & ND & ND & Clear solution \\
Caffeic acid & ND & 0.04 & Clear solution \\
Quinic acid & ND & ND & Suspension \\
\hline
\end{tabular}

$\mathrm{ND}<0.02 \mu \mathrm{g} / \mathrm{ml}$

* After bubbling: Each test solution was bubbled with air $(0.8 \mathrm{~L} / \mathrm{min})$ for $3 \mathrm{hr}$.

Concentration of each component: $100 \mu \mathrm{g} / \mathrm{ml}$
Table 6 に示したように, ばい煎前ではいずれの成分 からも $\mathrm{H}_{2} \mathrm{O}_{2}$ は検出されなかったが，ばい煎後からは数 種の成分から $\mathrm{H}_{2} \mathrm{O}_{2}$ の生成が見られ, その生成量はショ 糖からが最も多く, 次いでコーヒ一酸, クロロゲン酸, グリシンの順であった。 しかし，カフェイン及びキナ酸 からは検出されなかった。 また，これらの成分を混合し て, ばい煎し浸出した液からは $0.8 \mu \mathrm{g} / \mathrm{ml}$ の $\mathrm{H}_{2} \mathrm{O}_{2}$ を検 出した. 各成分の $\mathrm{H}_{2} \mathrm{O}_{2}$ 生成率はコーヒ一酸が最も高か った.

$\mathrm{H}_{2} \mathrm{O}_{2}$ を比較的多く生成したショ糖, クロロゲン酸及 びコーヒー酸について，ばい煎時間並びにばい煎温度が

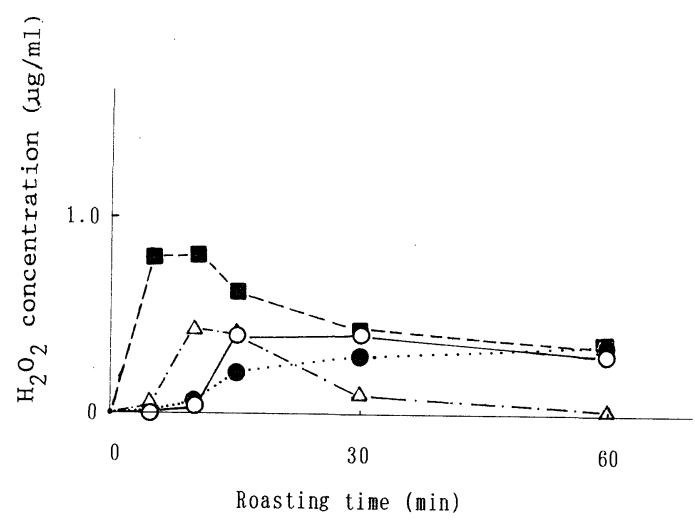

Fig. 6. Effects of roasting time on $\mathrm{H}_{2} \mathrm{O}_{2}$ contents in infusion of roasted coffee components Roasting temperature: $200^{\circ} \mathrm{C}$

a: mixture of 6 components; $\triangle$ : saccharose; : chlorogenic acid; $\bigcirc$ : caffeic acid

Table 6. Concentration of $\mathrm{H}_{2} \mathrm{O}_{2}$ in Infusion before and after Roasting of Various Coffee Components

\begin{tabular}{|c|c|c|c|c|}
\hline \multirow[b]{2}{*}{ Coffee components } & Before roasting & \multicolumn{3}{|c|}{ After roasting } \\
\hline & \multicolumn{2}{|c|}{ Content of $\mathrm{H}_{2} \mathrm{O}_{2}(\mu \mathrm{g} / \mathrm{ml})$} & Appearance & $\begin{array}{l}\text { Formation rate } \\
(\mathrm{mg} \%) \text { of } \mathrm{H}_{2} \mathrm{O}_{2}{ }^{2}\end{array}$ \\
\hline Saccharose & ND & $0.39(* 9.36)$ & Brown & 5.85 \\
\hline Chlorogenic acid & ND & $0.20(4.80)$ & Red & 3.43 \\
\hline Glycine & ND & $0.04(0.96)$ & Brown & 2.29 \\
\hline Caffeine & ND & $\mathrm{ND}(0.00)$ & Colorless & 0.00 \\
\hline Caffeic acid & ND & $0.24(5.76)$ & Dark purple & 96.00 \\
\hline Quinic acid & ND & $\mathrm{ND}(0.00)$ & Colorless & 0.00 \\
\hline Mixture of 6 components & ND & $0.81(19.44)$ & Brown & 46.00 \\
\hline Coffee beans ( $2 \mathrm{~g}$ ) & ND & $0.90(21.60)$ & Brown & 10.80 \\
\hline
\end{tabular}

$\mathrm{ND}<0.02 \mu \mathrm{g} / \mathrm{ml}$

Average of 3 determinations

The amount of each component described in Table 4 was used.

Each component was roasted, infused and determined.

*1 The figures in the parentheses indicate absolute amounts of $\mathrm{H}_{2} \mathrm{O}_{2}$.

*2 Absolute amount of $\mathrm{H}_{2} \mathrm{O}_{2}$ in each component was divided by the amount of used component, resepectively. 


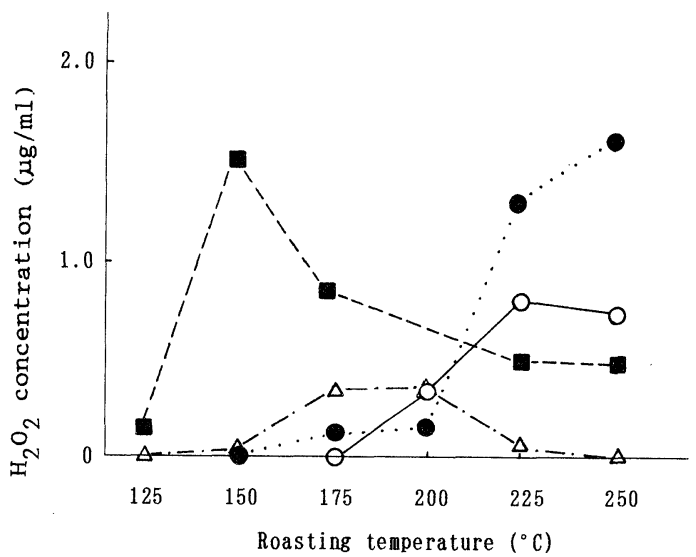

Fig. 7. Effects of roasting temperature on $\mathrm{H}_{2} \mathrm{O}_{2}$ contents in infusion of roasted coffee components

Roasted time: $15 \mathrm{~min}$

: mixture of 6 components; $\triangle$ : saccharose;

: chlorogenic acid; $\bigcirc$ : caffeic acid

$\mathrm{H}_{2} \mathrm{O}_{2}$ 生成にどのように関与するかを検討した。

Fig. 6 に示したように, ショ糖はばい煎時間が長くな るに従い, $\mathrm{H}_{2} \mathrm{O}_{2}$ の生成が少なくなった。これはばい煎に より, ショ糖が分解し, カラメル化する速度が早い ${ }^{17)}$ とによると考えられ，実際に，外見的にも炭化が一部見 られた。 クロロゲン酸及びコーヒ一酸の場合はばい煎時 間が長くなっても $\mathrm{H}_{2} \mathrm{O}_{2}$ の生成量は一定であり，外見上 の変化はショ糖に比較して焦げている度合は少なかっ た．混合成分の場合は，外見上各成分単独のときよりあ 早く焦げ炭化まで進んでいた，そのため, $\mathrm{H}_{2} \mathrm{O}_{2}$ の生成が 各成分単独の場合に比較して初期に多く，一部炭化する ことにより， $\mathrm{H}_{2} \mathrm{O}_{2}$ の生成が起こらなくなったと考えら れる. したがって, 混合成分では, 各成分が相互作用し て, 熱分解が成分単独の場合よりも早くなり, 漸次熱分 解していって炭化したと考えられ, 初期の熱分解物から $\mathrm{H}_{2} \mathrm{O}_{2}$ が生成されると考えられる.

Fig. 7 に示したように, 各成分からの $\mathrm{H}_{2} \mathrm{O}_{2}$ の生成は 温度の影響を受け, ショ糖に比較して, クロロゲン酸及 びコーヒ一酸の方が大きい. 又, $\mathrm{H}_{2} \mathrm{O}_{2}$ の生成量は $225^{\circ}$ と $250^{\circ}$ で特に大きい.すなわち, ショ糖の分解は温度が 高いほど早くなり, 炭化が進み, 高温のときは $\mathrm{H}_{2} \mathrm{O}_{2}$ 前 駆物質はすでに分解してしまったと考えられる。一方, クロロゲン酸はコーヒ一酸とキナ酸との縮合物 (Fig. 1) であるため, 熱により, コーヒ一酸とキナ酸への分解か ら更に $\mathrm{H}_{2} \mathrm{O}_{2}$ 前駆物質へと分解していっていると考えら れる.したがって，コーヒ一酸は生豆に含まれているだ けではなく，焙り豆及びインスタントコーヒーにも常に

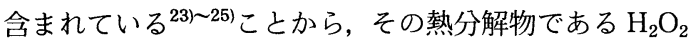
前駆物質も含まれていると考えられる。

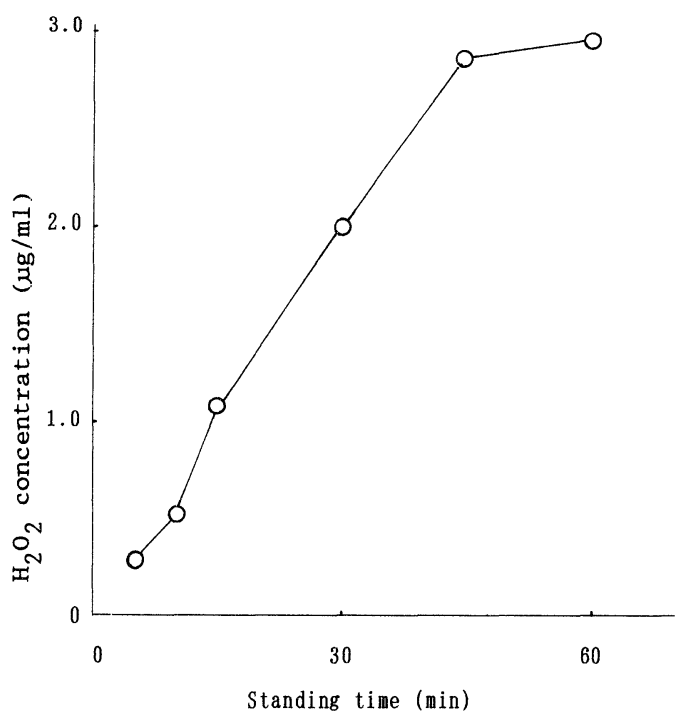

Fig. 8. Effects of standing time on $\mathrm{H}_{2} \mathrm{O}_{2}$ content in infusion of roasted caffeic acid Roasting temperature: $200^{\circ} \mathrm{C}$; roasting time: $15 \mathrm{~min}$ $p$-vinyl catechol

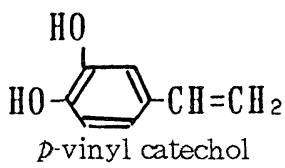

Fig. 9. Chemical structure of $p$-vinyl catechol

\section{3 ばい煎したコーヒー酸からの $\mathrm{H}_{2} \mathrm{O}_{2}$ 生成の経 時変化}

ばい煎したコーヒー酸の浸出液を保存したときの $\mathrm{H}_{2} \mathrm{O}_{2}$ 生成の経時変化を検討した.

Fig. 8 に示したように, ばい煎したコーヒ一酸の浸出 液を放置することにより $\mathrm{H}_{2} \mathrm{O}_{2}$ は増加した。

コーヒー酸は加熱することにより脱炭酸が起こり, Fig. 9 に示したような $p$-ビニルカテコールになり，これ が直ちに重合するといわ的ている ${ }^{31}$. この $p$-ビニルカテ コールが空気酸化してケト体になると同時に $\mathrm{H}_{2} \mathrm{O}_{2}$ が生 成されたのではないかと考える.

これらのことから，コーヒ一成分から $\mathrm{H}_{2} \mathrm{O}_{2}$ が生成し てくることが推察される.したがって, $\mathrm{H}_{2} \mathrm{O}_{2}$ を測定する 場合は溶存酸素の影響の少ない酸素電極法(2)及び(3)で行 うことにより, 真の值が得られると考える. また, 浸出 あるいは抽出直後のコーヒーは $\mathrm{H}_{2} \mathrm{O}_{2}$ 量が非常に少ない が, 保存している間に, 溶存酸素の影響で $\mathrm{H}_{2} \mathrm{O}_{2}$ が生成 してくる. その量は食品衛生上問題はないが, 溶存酸素 は $\mathrm{H}_{2} \mathrm{O}_{2}$ の生成ばかりではなく，味及び香りなどの品質 を少化させるので, 飲用するには入れたてのコーヒーの 方が良い26b). また，保存する場合でも，溶存酸素を絶っ 
た方法，すなわち，蓋をしたり，ホットプレート上に置 いたり, 臸素置換したりすることにより $\mathrm{H}_{2} \mathrm{O}_{2}$ 量の増加 を防ぎ，味，香りの変化が少ない．

\section{まとめ}

コーヒ一中の $\mathrm{H}_{2} \mathrm{O}_{2}$ 含量に影響を及ぼす要因につい て, 酸素電極法及び改良 4-アミノアンチピリン法を用い て検討し，次のような知見が得られた。

1) $\mathrm{H}_{2} \mathrm{O}_{2}$ であることの確認を TLC で行った.

2) 酸素電極法及び改良 4-アミノアンチピリン法によ る定量值が同じであった，脱脂の影響はなかった。

3）生コーヒ一豆からは $\mathrm{H}_{2} \mathrm{O}_{2}$ を検出しなかった。 コ 一七一豆のばい煎度が深いほよ゙ $\mathrm{H}_{2} \mathrm{O}_{2}$ 含量が増加し, 光 照射, $30^{\circ}, 100$ 日間保存した焙り豆中の $\mathrm{H}_{2} \mathrm{O}_{2}$ 含量は約 $300 \mu \mathrm{g} / \mathrm{g}$ であった。 ドリップ式コーヒーメーカーで浸 出あるいは溶解したものの $\mathrm{H}_{2} \mathrm{O}_{2}$ 含量は $0.6 \mu \mathrm{g} / \mathrm{ml}$ 以下 であり， ろ過器で浸出あるいは溶解したものは約 10 倍 となり, 溶存酸素によるコーヒ一成分からの $\mathrm{H}_{2} \mathrm{O}_{2}$ 生成 が考えられる.

4) コーヒ一豆の成分であるショ糖, クロロゲン酸, グリシン，カフェイン，コーヒ一酸及びキ+酸から $\mathrm{H}_{2} \mathrm{O}_{2}$ は検出されなかった. しかし, これらの成分をコー ヒ一豆と同様にばい煎して浸出した液のうち, ショ糖,

クロロゲン酸, グリシン及びコーヒー酸から $\mathrm{H}_{2} \mathrm{O}_{2}$ を検 出した。ばい煎したコーヒ一酸からの $\mathrm{H}_{2} \mathrm{O}_{2}$ の生成率が 他の成分よりも高かった。 コーヒ一酸の就分解物がコー 七一中の $\mathrm{H}_{2} \mathrm{O}_{2}$ 生成前駆物質とし一番大きく寄与するも のと考えられる.

\section{謝辞}

各国の生コーヒ一豆，それらの焙り豆及びインスタン トコーヒ一を提供して戴いた全日本コーヒ一協会に深謝 いたします。

文献

1) Nagao, M., Takahashi, Y., Yamanaka, H., Sugimura, T.: Mutation Res. 68, 101 106 (1979).

2) Kosugi, A., Nagao, M., Suwa, Y., Wakabayashi, K., Sugimura, T.: ibid., 116, 179 184 (1983).

3) Fujita, Y., Wakabayashi, K., Nagao, M., Sugimura, T.: ibid. 142, 145 148 (1985).

4) Friederich, U., Hann, D., Albertini, S., Schlatter, Ch., Wurgler, F. E.: ibid., 156, 39 52 (1985).

5) Aeschbacher, H. U., Ruch, E., Meier, H., Wurzner, H. P., Munoz-Box, R.: Food Chem. Toxicol. 23, 747 752 (1985).

6) Suwa, Y., Nagao, M., Kosugi, A., Sugimura, T.: Mutation Res., 102, 383 391 (1982).

7) Nakasato, F., Nakayasu, M., Fujita, Y., Nagao, M., Terada, M., Sugimura, T.: ibid., 141, 109 112 (1984).

8) Fujita, Y., Wakabayashi, K., Nagao, M., Sugimura, T.: ibid., 144, $227 \sim 230$ (1985).

9) Ariza, R. R., Dorado, G., Barbancho, M., Pueyo, C.: ibid., 201, 89 96 (1988).

10) Aeschbacher, H. U., Wolleb, U., Loliger, J., Spadone, J. C., Liardon, R.: Food Chem. Toxicol. 27, 227 232 (1989).

11) Peinado, J., Toribio, F., Perez-Bendito, D.: Anal. Chem. 58, 1,725 1,729 (1986).

12) Rinkus, S. J., Taylor, R. T.: Food Chem. Toxicol. 28, 323 $\sim 331$ (1990)

13）辻 澄子, 中村優美子, 外海泰秀, 柴田 正, 内堀伸健, 川田誠, 小林建夫, 鈴木 宏, 室井順子, 鈴木由記子, 兼田 登, 鈴木英喜, 宮本文夫, 伊藤誉志男：日食工誌. 37, 111 123 (1990).

14）厚生省生活衛生局監修：“食品衛生検查指針一食品中の食 品添加物分析法一” p. 68〜 71 (1989) 日本食品衛生協会.

15) Toyoda, M., Ito, Y., Iwaida, M., Fujii, M.: J. Agric. Chem., 30, 346 349 (1982).

16) Ito, Y., Tonogai, Y., Suzuki, H., Ogawa, S., Yokoyama, T., Hashizume, T., Santo, H., Tanaka, K., Nishigaki, K., Iwaida, M.: J. Assoc. Off. Anal. Chem. 64, 1,448 1,452 (1981).

17）中林敏郎，渡辺千賀子：日食工誌．24，124～129 (1977).

18）中林敏郎, 児島裕二郎：同上 $27,108 \sim 111$ (1980).

19）日本化学会編：“化学便覧基礎編 II” 改訂 3 版, p. 355 (1984) 丸善.

20）辻 澄子, 石田浩平, 中村優美子, 外海泰秀, 江川 宏, 伊藤誉志男：食衛誌. 28, 445 452 (1987).

21）日本薬学会編：“衛生試験法注解” p. 187 188 (1990) 金 原出版.

22）山東英幸, 橋爪 崇, 横山 剛：食衛誌. $23,325 \sim 330$ (1982).

23) Sivetz, M., Desrosier, N. W.: "Coffee Technology" p. 560 $\sim 697$ (1979), Avi Publ. Comp. Inc., Westport, Connecticut.

24) Feldman, J. R., Ryder, W. S., Kung, J. T.: J. Agr. Food Chem. 17, 733 739 (1969).

25) Maier, H. G.: “Kaffee” p. 61 (1981) Verlag Plaul Parey, Berlin und Hamburg.

26）工業技術会編：“コーヒーとお茶の現況と展望” (a) p. 90〜 105 (1989), (b) p. 142 163 (1989) 工業技術会.

27）野村男次, 大村浩久：“レダクトンの化学” p. 307 337 (1969) 内田老鶴圃新社.

28) Cilliers, J. J. L., Singleton, V. L.: J. Agric. Food Chem 37, 890 896 (1989).

29) Hanham, A. F., Dunn, B. P., Stich, H. F.: Mutation Res. 116, 333 339 (1983).

30）中林敏郎，鈴木邦男：日食工誌. 33, 779 782 (1986).

31）中林敏郎：“世界のコーヒ一生産国” 全日本コーヒ一協会 編, p. 219 (1985). 